\title{
A Cost Analysis Case Study Of A Small Chinese Manufacturer
}

Steven P. Landry, Ph.D., CPA, Naval Postgraduate School, USA

Canri Chan, Ph.D., CPA, Monterey Institute of International Studies, USA

\begin{abstract}
This study investigated whether a small firm, China Umbrella Factory Limited (CUFL), and in fact any firm in a developing country (mainland China), could benefit from a formal, activitybased costing system. ${ }^{l}$ Many small firms, even more so than larger firms, find themselves particularly vulnerable to competitive challenges because the smaller firms lack the know-how and resources to know their true costs and profit margins. Smaller firms tend to use heuristics, or rules-of-thumb, in their estimation of costs as opposed to the bonafide use of more sophisticated and validated costing systems, whether traditional or activity-based costing (ABC). Comparisons of this firm's current estimations of costs were made using both of these costing systems. Results indicated differences across the three methods. It was discovered that cost distortions that disfavored the estimation and traditional methods favored the ABC method. Notwithstanding the benefits found with using $A B C$, the firm decided not to adopt this method. A major constraining factor rested with the limitation of human resources - particularly with training in $A B C$ as well as general management accounting. Furthermore since $A B C$, in a greater fundamental sense, benefits firms with significant overhead (when measured as a proportion of total cost), ABC would only provide limited benefits relative to the cost of implementation given the low-tech, primarily labor-based nature of this firm and its products.
\end{abstract}

Keywords: Cost Analysis Case Study; Small Chinese Manufacturer; Activity Based Costing; Rule of Thumb Costing

\section{INTRODUCTION}

\section{Background and Objective of the Study}

s firms face rapidly changing technologies and volatile markets, small firms are particularly vulnerable to competitive challenges. Such firms tend to spend more time adjusting to, rather than predicting and controlling, the business environment. From marketing and cost perspectives, most small manufacturing companies cannot separate winners from losers. They do not know which products, services, customers and markets are most profitable. Worse still, they are unable to rely on their own heuristics, which tend to distort the true view of profitability. Furthermore, they find it difficult to know where to improve to become more efficient. More often than not they spend too much energy fixing problems that yield little measurable benefit. On the other hand, it should be noted that in some cases, improvement efforts may actually reduce profitability particularly in the short run. Small firms with small profit margins may not have the luxury of sacrificing short-term profits for the long-term.

\footnotetext{
${ }^{1}$ This study was, in fact, conducted in a real company with manufacturing operations in China and with a marketing office in Hong Kong. However, to protect the proprietary information of this company, the name of the firm, the name of the owner, and the specific China city have all been changed. Furthermore, the year of the study has been labeled as ' $201 \mathrm{X}$ ' for the same reason. The actual numerical information in the study was correct to the best knowledge of the owner who allowed its use given the masking of his firm's identity.
} 
Similarly, assigning overhead to products in traditional ways has drawn criticism. Traditional costing systems have been argued against principally by Activity-Based Costing (ABC) advocates. Running any business inherently means making important internal decisions such as product mix, product pricing, etc. Traditional costing systems are designed mainly for financial reporting and for internal, management decision making. By contrast, traditional $\mathrm{ABC}$ deliberately attempts to address the problem of suboptimal overhead allocation problem. This research project evaluated whether or not small manufacturing companies can better benefit from ABC. One small company in particular was analyzed in depth.

\section{RESEARCH METHODOLOGY}

The China Umbrella Factory Limited (CUFL) agreed to participate in this study and met our objective of evaluating a small company (Megginson, et. al. 1988; Steinhoff and Burgess, 1993). This study utilized both faceto-face and telephone interviews during the data collection process. The owner was very enthusiastic to participate in the project. Therefore, the owner provided a rich supply of data and detailed descriptions of the production processes of umbrella making. Calculations were done using both traditional costing and $\mathrm{ABC}$ formats after the collection of all cost data. Comparisons of CUFL's existing pricing system, traditional costing system and ABC followed. Whether CUFL should use ABC as its costing system was addressed through the data obtained stemming from the discussion questions at the end of the case.

\section{Benefits of Activity-Based Costing}

The two important advocates of ABC, Cooper and Kaplan (1988), discussed the three benefits of ABC: 1) improved decisions, 2) continuous improvement activities, and 3) ease of determining relevant costs.

Improved Decisions: The possibility of managers making poor decisions is reduced due to more informative product cost information. This in turn, improves insights into managing the activities that lead to overhead costs, and provides easier access to relevant costs for a wider range of decisions.

Continuous Improvement Activities: Activity-based costing provides information that supports performanceimproving activities in several ways. First, it identifies the amount of expenses currently being spent on activities where performance can be substantially improved. Second, organizations that are already making quality improvement through just-in-time activities need a financial model to help set priorities in order that the organization is better able to focus on the activities that have the largest opportunities for improvement. Finally, organizations that periodically re-estimate their activity-based models can learn whether operating improvements have, in fact, translated into improved profitability through higher revenues and reduced resource spending.

Ease of Determining Relevant Costs: Traditional product cost data should be adjusted to obtain information relevant for a particular decision. However, $\mathrm{ABC}$ reduces the need to perform special studies by both increasing the accuracy of reported product costs and, unlike traditional systems, reporting separately the costs of four different categories (unit-level, batch-level, product-level, and facility-level) of activities.

$\mathrm{ABC}$ is necessary to actually trace overhead costs to cost objects and thus properly account for diverse business environments (Cooper and Kaplan 1988), batch- and product-level costs (Cooper 1990), manufacturing complexity (Jones 1991), and specialty product costs (Shrindhi 1992). Numerous proponents of ABC recommend using this system to develop cost-effective product design (Cooper and Turney 1989) and to support process improvement (Turney 1991). Also, many current Management Accounting textbooks cover ABC in detail (Horngren, et al., 2009 and Garrison, et al., 2012 as examples).

\section{THE CASE STUDY}

\section{Company Background}

As the name suggests, the main operation of the China Umbrella Factory Limited (CUFL), is the manufacturing of umbrellas. It is a private company located in Peoples Republic of China (PRC). It is owned by a 
husband and wife (whom we will call Mr. and Mrs. Wong).). There are about 450 workers in total. The management office is located in Hong Kong and has 5 employees. Mr. Wong, as the managing director, manages all the affairs related to the company. He uses estimating techniques based on "his experience" to cost the various models of umbrellas. CUFL's products range from general purpose umbrellas, to advertising umbrellas, to beach and golf umbrellas, to fashion umbrellas. Most of the products are exported to European countries. Special designs and specifications are accommodated as required by customers.

\section{Manufacturing Process}

The manufacturing process commences upon receiving a customer order by a sales clerk in Hong Kong, who then passes the details of the order to Mr. Wong. Mr. Wong then asks the factory manager to check whether there are enough materials in the PRC warehouse. If the required materials are not available (which is typically the case), Mr. Wong will ask the purchasing clerk to order the necessary materials, e.g., shafts, cloths, and other parts (mainly handles).

The materials are shipped by the suppliers to the warehouse in the PRC. Materials are sent to the shop floor by batches when needed. Materials are delivered to three divisions, Frame Assembly, Cuttings, and Gross Assembly, for their operations. Frame parts are delivered to the Frame Assembly Division for assembly of the frame. Nylon cloth is delivered to the Cuttings Division, which consists of two cutting operations. The division will first cut the rolls of nylon into size-fit (i.e., rectangle 24" width for a regular umbrella), then cut the size-fit into triangles (panels). Other parts are delivered to the Gross Assembly Division.

After the frame assembly and cutting divisions finish their work, they pass their output to the Sewing Division. In Sewing, the frame and nylon triangles are sewn together and this output is passed to the Gross Assembly Division. Gross Assembly combines the pieces into the finished product. The finished products are subject to after-production inspection quality control. Disqualified products are generally returned to Sewing for rework, and qualified products are packed using both inner boxes and outer boxes for delivery. Figure 1 illustrates the manufacturing process.

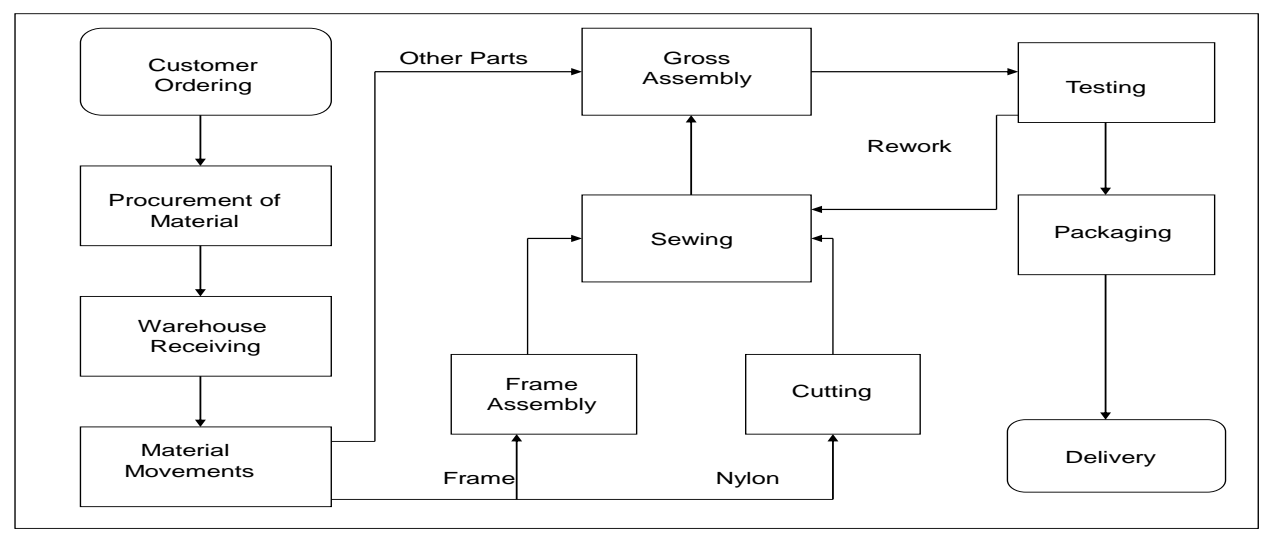

Figure 1 The Manufacturing Process of China Umbrella Factory Limited

\section{FINDINGS AND DISCUSSION}

\section{Comparison of Product Costing}

Three different costing approaches were carried out to calculate the product cost of CUFL to decide whether CUFL suffers from its prevailing pricing system and whether it could benefit from ABC. In order to calculate the product cost using $\mathrm{ABC}$, various information typically needed is usually unavailable for a small 
manufacturing company unless special efforts are made. Mr. Wong tried to analyze CUFL's cost in August, 201X. Unfortunately, he became overwhelmed with other aspects of the business, so his analysis was never completed. Nevertheless, the August 201X cost data was taken as a start point to perform this comparison noting its existence as the most comprehensive data available. In August 201X, there were 21 orders in the production process. Fourteen of the orders were finished and delivered to the customers. The breakdown of direct materials, direct labor, and description of the orders are shown in Table 1.

\section{Prevailing Product Costing of CUFL (Estimating Technique)}

CUFL used two models (A and B) for pricing while noting the business competition situation. Product price using Model A was derived from direct materials plus direct labor with a premium added. The premium was expected to cover the estimated "other costs" and generate a profit. When there were plenty of production orders in process, Model A applied. However, Mr. Wong said, "The competition is keen these days. The price of the umbrellas is market determined, and I can only try to cover the costs. Sometimes I will accept a price lower than the costs because factory costs are fixed. If I don't accept the order I still need to pay the fixed costs!" As a result, Mr. Wong would sometimes use the product pricing approach known as Model B which simply priced a given umbrella at a comparable market price or maybe less depending on Mr. Wong's judgment of current market competition.

The direct materials, direct labor, premiums, and prices under the owners' Models A and B are listed in Table 2. (Prices, to be consistent in presentation, have been converted into Hong Kong dollars - HK\$). The implicit premiums are derived by subtracting the prices of Model B from Model A, noting that all prices were obtained from Mr. Wong. Looking at the product premiums, we find that some of the products have less of a premium than others. For example, order number 1 has $\$ 13.18(11.73 \%)$ of the Model A price when compared with that of order number 13 for $\$ 49.58(23.69 \%)$. This may have been due to keen competition at which time the product must sell at less of a premium. In fact, assuming Mr. Wong thought he made a profit on all orders, we can conclude from the premium, for example looking at order number 1, that the estimated manufacturing overhead related to the products was less than $\$ 13.18$. To address whether this figure is correct, two costing techniques will attempt to verify this conclusion traditional cost system and activity-based costing.

Table 1 Production Cost Data

\begin{tabular}{|c|c|c|c|c|c|c|c|}
\hline \multirow[b]{2}{*}{ Order \# } & \multirow[b]{2}{*}{ Description } & \multicolumn{6}{|c|}{ Direct Materials } \\
\hline & & Frames & Cloths & $\begin{array}{c}\text { Handles } \\
\text { \& caps }\end{array}$ & Tips & Total D.M. & $\begin{array}{l}\text { Direct } \\
\text { Labor }\end{array}$ \\
\hline & & $\$ / \mathrm{DOZ}$ & $\$ / \mathrm{DOZ}$ & $\$ / \mathrm{DOZ}$ & $\$ / \mathrm{DOZ}$ & $\$ / \mathrm{DOZ}$ & $\$ / \mathrm{DOZ}$ \\
\hline 1 & 23"x8 regular, auto, single & 36.70 & 50.00 & 7.80 & & 94.50 & 4.70 \\
\hline 2 & 20"x8 foldable, auto, single & 44.51 & 38.00 & 15.49 & 4.23 & 102.23 & 6.66 \\
\hline 3 & 21"x8 mini, multiple & 45.07 & 38.00 & 7.34 & & 90.41 & 5.59 \\
\hline 4 & 23"x8 regular, auto, multiple & 50.70 & 50.00 & 6.88 & & 107.58 & 5.72 \\
\hline 5 & 21"x8 mini, color & 59.15 & 38.00 & 7.34 & & 104.49 & 4.96 \\
\hline 6 & 15.5"x8 regular, auto, single & 29.58 & 33.00 & 9.86 & & 72.44 & 5.23 \\
\hline 7 & 15.5"x8 regular, auto, edge, color & 29.58 & 45.00 & 9.86 & & 84.44 & 5.91 \\
\hline 8 & 21 "x8 mini, multiple & 42.25 & 46.00 & 7.34 & & 95.59 & 4.93 \\
\hline 9 & 20"x8 regular, auto, multiple & 36.62 & 38.00 & 7.80 & & 82.42 & 4.64 \\
\hline 10 & 21"x8 mini, single & 42.25 & 38.00 & 7.34 & & 87.59 & 4.94 \\
\hline 11 & 20"x8 regular, auto, multiple & 36.62 & 38.00 & 7.80 & & 82.42 & 5.70 \\
\hline 12 & 21"x8 regular, auto, color & 36.62 & 60.00 & 7.80 & & 104.42 & 4.71 \\
\hline 13 & 27"x8x2 golf, multiple & 70.42 & 73.00 & 7.80 & 2.25 & 153.47 & 6.20 \\
\hline 14 & $27 " x 8 \times 2$ golf, multiple & 70.42 & 73.00 & 7.80 & 2.25 & 153.47 & 6.20 \\
\hline 15 & $27 " x 8 \times 2$ golf, multiple & 70.42 & 73.00 & 7.80 & 2.25 & 153.47 & 6.20 \\
\hline 16 & $27 " x 8 \times 2$ golf, multiple & 70.42 & 73.00 & 7.80 & 2.25 & 153.47 & 6.20 \\
\hline 17 & 27"x8x2 golf, multiple & 70.42 & 73.00 & 7.80 & 2.25 & 153.47 & 6.20 \\
\hline 18 & 20"x8 regular, auto, multiple & 36.62 & 38.00 & 7.80 & & 82.42 & 4.64 \\
\hline 19 & 21"x8 mini, single & 42.25 & 38.00 & 7.34 & & 87.59 & 4.94 \\
\hline 20 & 23 "x8 regular, auto, multiple & 64.79 & 73.00 & 18.31 & & 156.10 & 5.32 \\
\hline 21 & 21"x8 mini, multiple & 42.25 & 46.00 & 7.34 & & 95.59 & 4.93 \\
\hline
\end{tabular}

\$/DOZ: means dollars per dozen 


\section{Traditional Cost System}

In this research, a simple traditional cost system was used for illustration (Ainsworth 1994; also Hornrgen, et al, 2009 and Garrison, et al., 2012). The details of manufacturing overhead are in Appendix I. There were $\$ 255,470.50$ of total manufacturing overhead for the month, and 17,591 equivalent units (one dozen per unit) were produced. Therefore, taking the total manufacturing overhead and dividing by 17,591 equivalent units obtains $\$ 14.52$, which could then be allocated to each unit assuming overhead ought to be assigned by output. (Assumptions and calculations of equivalent units are in Appendix II). However, traditional overhead calculations generally apply overhead to some input activity. In this case, assume overhead is to be applied on Direct Labor Dollars (DL\$), and that the total DL\$ in this period were $\$ 91,566.49$. This labor and overhead data should be used to calculate an overhead rate and assign overhead to the various jobs. Table 3 delineates the traditional costing method data.

\section{Activity-Based Costing}

As mentioned in the introduction, product costs calculated under traditional cost systems can be inaccurate and distorted in some cases. Therefore, an examination utilizing ABC to calculate the product costs was conducted next. A summary of the activities and cost drivers are listed in Table 4 and the detailed breakdown is provided in Appendix III. Following typical ABC methodology, four unit-level activities (assembling, cuttings, sewing, and packaging) and four batch-level activities (materials procurement, materials handling, inspection, and delivery) were identified. The description of the activities and their related cost follows:

Table 2 Owner's Costing Method

\begin{tabular}{|l|c|c|c|c|c|c|c|}
\hline$*$ Order & Unit & Dir. Materials & Direct Labor & Price Model A & Premium & Price Model B & Premium \\
\hline \# & $\$ / \mathrm{DOZ}$ & $\$ / \mathrm{DOZ}$ & $\$ / \mathrm{DOZ}$ & $\$ / \mathrm{DOZ}$ & $\$ / \mathrm{DOZ}$ & $\$ / \mathrm{DOZ}$ & $\%$ \\
\hline 1 & 1,000 & 94.50 & 4.70 & 112.38 & 13.18 & 99.19 & 11.73 \\
\hline 2 & 500 & 102.23 & 6.66 & 143.38 & 34.49 & 108.88 & 24.06 \\
\hline 3 & 420 & 90.41 & 5.59 & 127.88 & 31.52 & 96.36 & 24.65 \\
\hline 4 & 600 & 107.58 & 5.72 & 130.20 & 16.89 & 113.31 & 12.97 \\
\hline 5 & 342 & 104.49 & 4.96 & 143.38 & 33.93 & 109.45 & 23.66 \\
\hline 6 & 50 & 72.44 & 5.23 & 104.63 & 26.96 & 77.67 & 25.76 \\
\hline 7 & 50 & 84.44 & 5.91 & 127.88 & 37.53 & 90.35 & 29.35 \\
\hline 8 & 2,800 & 95.59 & 4.93 & 143.38 & 42.85 & 100.53 & 29.88 \\
\hline 9 & 1,000 & 82.42 & 4.64 & 118.58 & 31.52 & 87.06 & 26.58 \\
\hline 10 & 1,500 & 87.59 & 4.94 & 130.20 & 37.67 & 92.53 & 28.93 \\
\hline 11 & 2,000 & 82.42 & 5.70 & 118.58 & 30.46 & 88.11 & 25.69 \\
\hline 12 & 200 & 104.42 & 4.71 & 137.95 & 28.82 & 109.13 & 20.89 \\
\hline 13 & 138 & 153.47 & 6.20 & 209.25 & 49.58 & 159.67 & 23.69 \\
\hline 14 & 150 & 153.47 & 6.20 & 209.25 & 49.58 & 159.67 & 23.39 \\
\hline 15 & 1,155 & 153.47 & 6.20 & 209.25 & 49.58 & 159.67 & 23.69 \\
\hline 16 & 2,500 & 153.47 & 6.20 & 209.25 & 49.58 & 159.67 & 23.69 \\
\hline 17 & 1,000 & 153.47 & 6.20 & 209.25 & 49.58 & 159.67 & 23.69 \\
\hline 18 & 1,000 & 82.42 & 4.64 & 118.58 & 31.52 & 87.06 & 26.58 \\
\hline 19 & 3,000 & 87.59 & 4.94 & 130.20 & 37.67 & 92.53 & 28.93 \\
\hline 20 & 750 & 156.10 & 5.32 & 182.13 & 20.71 & 161.42 & 11.37 \\
\hline 21 & 1,000 & 95.59 & 4.93 & 143.38 & 42.85 & 100.52 & 29.89 \\
\hline$*$ Order & & & & & & \\
\end{tabular}

* Orders numbered 1-14 finished in August and shipped to customers

Materials Procurement: There is one clerk in the Hong Kong office who is responsible for the procurement of materials. Almost every order involves the same amount of work. This is a batch-level activity and the cost driver for this activity is the number of customer orders.

Materials Handling: Three major kinds of materials requiring handling are: frames, cloth, and other parts. The materials in the warehouse are moved to the factory if needed. This is a batch-level activity and the cost driver is the number of movements (transfers). 
Cuttings: The cloth (nylon) is transferred from the warehouse to the cutting machine for cutting into size-fit. If the product involves only one color of cloth, the cutting process is simple. However, if the product requires 8 different colors for 8 panels, then cutting work increases. Cloth is cut into panels ( 8 triangles for an umbrella). The cutting activity is estimated by Mr. Wong, who indicated that multiple colors need 4 times more than that of a single color. This is a unit-level activity with the cost driver being the number of cuttings.

Assembly: The frames are assembled at the same time as the cutting operation was performed. Then, the frames and fabric are combined. Other items (handles, caps, tips, etc.) are attached. Assembly is a unit-level activity and the cost driver identified for this activity is the number of items (parts and/or subassemblies) used in assembling the umbrellas.

Sewing: Prior to other assembly operations, cloth cuttings are sewn together and attached to the frame. Depending on the model specifications, additional needlework connects other items, such as artwork to the cloth. Sewing is identified as a unit-level activity and the cost driver is the number of items to be sewn together less one (e.g., two items sewn together will be on activity one; 3 items sewn together will be 2 , and so forth).

Packaging: After assembly, the umbrellas are sent to packaging. There are several kinds of packaging, namely plastic bags for the handle, and separate plastic bags for the whole umbrella, etc. This is a unit-level activity and the cost driver selected is the number of parts needed to pack the umbrella case.

Inspection: There is a sample inspection conducted by a quality controller after the completion of the umbrellas. This is a batch-level activity and the cost driver for this inspection activity is the number of samples to test.

Table 3 Product Cost under Traditional Costing System and Related Profit/Loss Under Model A Pricing

\begin{tabular}{|c|c|c|c|c|c|c|c|c|}
\hline Order \# & $\begin{array}{c}\text { Price } \\
\text { Model A }\end{array}$ & $\begin{array}{c}\text { Equivalent Units } \\
\text { Produced }\end{array}$ & $\begin{array}{c}\text { Direct } \\
\text { Materials }\end{array}$ & $\begin{array}{l}\text { Direct } \\
\text { Labor }\end{array}$ & $\begin{array}{c}\text { Allocated } \\
\text { OH }\end{array}$ & $\begin{array}{l}\text { Trad. } \\
\text { Cost }\end{array}$ & $\begin{array}{l}\text { Trad. } \\
\text { P/L }\end{array}$ & $\begin{array}{l}\text { Trad. } \\
\text { P/L \% }\end{array}$ \\
\hline & $\$ / \mathrm{DOZ}$ & $\$ / \mathrm{DOZ}$ & $\$ / \mathrm{DOZ}$ & $\$ / \mathrm{DOZ}$ & $\$ / \mathrm{DOZ}$ & $\$ / \mathrm{DOZ}$ & $\$ / \mathrm{DOZ}$ & \\
\hline 1 & 112.38 & $1,000.00$ & 94.5 & 4.70 & & & & \\
\hline 2 & 143.38 & 500.00 & 102.23 & 6.66 & & & & \\
\hline 3 & 127.88 & 420.00 & 90.41 & 5.59 & & & & \\
\hline 4 & 130.20 & 600.00 & 107.58 & 5.72 & & & & \\
\hline 5 & 143.38 & 342.00 & 104.49 & 4.96 & & & & \\
\hline 6 & 104.63 & 50.00 & 72.44 & 5.23 & & & & \\
\hline 7 & 127.88 & 50.00 & 84.44 & 5.91 & & & & \\
\hline 8 & 143.38 & $2,800.00$ & 95.59 & 4.93 & & & & \\
\hline 9 & 118.58 & $1,000.00$ & 82.42 & 4.64 & & & & \\
\hline 10 & 130.20 & $1,500.00$ & 87.59 & 4.94 & & & & \\
\hline 11 & 118.58 & $2,000.00$ & 82.42 & 5.70 & & & & \\
\hline 12 & 137.95 & 200.00 & 104.42 & 4.71 & & & & \\
\hline 13 & 209.25 & 138.00 & 153.47 & 6.20 & & & & \\
\hline 14 & 209.25 & 150.00 & 153.47 & 6.20 & & & & \\
\hline 15 & 209.25 & $1,018.33$ & 153.47 & 6.20 & & & & \\
\hline 16 & 209.25 & $2,039.67$ & 153.47 & 6.20 & & & & \\
\hline 17 & 209.25 & 333.33 & 153.47 & 6.20 & & & & \\
\hline 18 & 118.58 & 544.67 & 82.42 & 4.64 & & & & \\
\hline 19 & 130.20 & $1,354.67$ & 87.59 & 4.94 & & & & \\
\hline 20 & 182.13 & 634.33 & 156.1 & 5.32 & & & & \\
\hline 21 & 143.38 & 916.00 & 95.59 & 4.93 & & & & \\
\hline
\end{tabular}


Table 4 Activity Analysis and Cost per Activity

\begin{tabular}{|l|l|l|r|r|r|}
\hline \multicolumn{1}{|c|}{ Activity } & \multicolumn{1}{|c|}{ Cost Drivers } & $\begin{array}{c}\text { Activity } \\
\text { Level }\end{array}$ & $\begin{array}{c}\text { No. of } \\
\text { Activities }\end{array}$ & Cost (\$) & Rate (\$) \\
\hline Assembly & No. of Assembling & Unit & 117,716 & $\$ 17,388.28$ & \\
\hline Cuttings & No. of Cuttings & Unit & 53,759 & $12,051.23$ & \\
\hline Sewing & No. of Sewing & Unit & 74,688 & $21,933.42$ & \\
\hline Packaging & No. of Packaging & Unit & 56,745 & $57,562.08$ & \\
\hline Materials Procurement & No. of Order & Batch & 63 & $8,500.00$ & \\
\hline Materials Handling & No. of Movement & Batch & 227 & $16,406.83$ & \\
\hline Delivery & No. of Delivery & Batch & 12 & $54,247.27$ & \\
\hline Inspection & No. of Inspection & Batch & 46 & 250.00 & \\
\hline General Admin. & No. of Units Produced & Facility & 17,591 & $\$ 67,131.38$ & \\
\hline Alternative General Admin & * Ratio & Facility & & $\$ 67,131.38$ & \\
\hline & & & Total: & $\$ 255,470.50$ & \\
\hline
\end{tabular}

* Ratio of General Administration Costs to Total Costs Before Facility Level

Delivery: The final activity consists of the umbrellas being delivered to customers by vehicle. The vehicles cost $\$ 1,100$ per delivery. Normally, a 20 -foot container can deliver up to 2,500 dozen umbrellas. The cost driver selected for this activity is the number of deliveries.

Concerning product-level activity, as Mr. Wong stated, the production of different models of umbrellas require very similar inputs, and no special input was needed to sustain production of the variety of products. Therefore, no product-level activity was separately identified. With regard to overhead not already classified by previously identified activities, such costs are pooled as facility-level activities. These costs include general administration, etc., which are allocated evenly according to the units produced (or alternatively the ratio of General Administrative Costs to Total Costs before considering Facility-Level Costs). A table of overhead categorized by activities is shown in Appendix IV. The facility-level activity pooled $\$ 67,131.38$ with a total of 17,591 equivalent units produced during the month. Therefore, the facility-level cost assigned per unit of umbrellas was $\$ 3.82$. ABC calculations by order number are shown in Table 5 . As only the orders with an asterisk (*) were finished during the month, other orders were converted to equivalent units based on Mr. Wong's estimates.

Table 5 Product Cost Calculated by Activity-Based Costing

\begin{tabular}{|c|c|c|c|c|c|c|}
\hline $\begin{array}{c}\text { Order \# listed } \\
\text { by product }\end{array}$ & $\begin{array}{c}\text { Direct Material } \\
\$ / \mathrm{DOZ}\end{array}$ & $\begin{array}{c}\text { Direct Labor } \\
\$ / \mathrm{DOZ}\end{array}$ & $\begin{array}{c}\text { Unit \& Batch Level } \\
\text { Activity Costs } \\
\text { \$/DOZ } \\
\end{array}$ & $\begin{array}{c}\text { Facility-Level } \\
\text { Cost Assigned } \\
\text { \$/DOZ } \\
\end{array}$ & $\begin{array}{c}\text { ABC OHD } \\
\$ / \mathrm{DOZ}\end{array}$ & $\begin{array}{c}\text { ABC Unit } \\
\text { Cost } \\
\text { \$/DOZ } \\
\end{array}$ \\
\hline 1 & 94.50 & 4.70 & $13,740.60$ & $3,816.23$ & & \\
\hline 2 & 102.23 & 6.66 & $8,906.47$ & $1,908.12$ & & \\
\hline 3 & 90.41 & 5.59 & $7,694.00$ & $1,602.82$ & & \\
\hline 4 & 107.58 & 5.72 & $10,627.57$ & $2,289.74$ & & \\
\hline 5 & 104.49 & 4.96 & $7,003.29$ & $1,305.15$ & & \\
\hline 6 & 72.44 & 5.23 & 766.28 & 190.81 & & \\
\hline 7 & 84.44 & 5.91 & 792.17 & 190.81 & & \\
\hline 8 & 95.59 & 4.93 & $28,043.52$ & $10,685.46$ & & \\
\hline 9 & 82.42 & 4.64 & $13,843.73$ & $3,816.23$ & & \\
\hline 10 & 87.59 & 4.94 & $13,872.72$ & $5,724.35$ & & \\
\hline 11 & 82.42 & 5.70 & $25,038.77$ & $7,632.47$ & & \\
\hline 12 & 104.42 & 4.71 & $6,525.06$ & 763.25 & & \\
\hline 13 & 153.47 & 6.20 & $3,929.56$ & 526.64 & & \\
\hline 14 & 153.47 & 6.20 & $4,012.70$ & 572.44 & & \\
\hline 15 & 153.47 & 6.20 & $8,777.81$ & $3,886.19$ & & \\
\hline 16 & 153.47 & 6.20 & $14,535.32$ & $7,783.86$ & & \\
\hline 17 & 153.47 & 6.20 & $1,846.01$ & $1,272.07$ & & \\
\hline 18 & 82.42 & 4.64 & $2,557.96$ & $2,078.59$ & & \\
\hline 19 & 87.59 & 4.94 & $4,021.57$ & $5,169.74$ & & \\
\hline 20 & 156.10 & 5.32 & $6,260.10$ & $2,420.75$ & & \\
\hline \multirow[t]{2}{*}{21} & 95.59 & 4.93 & $5,543.88$ & $3,495.67$ & & \\
\hline & & Total: & $188,339.09$ & $67,131.39$ & & \\
\hline
\end{tabular}




\section{DISCUSSION QUESTIONS}

1. Develop a spreadsheet or set of spreadsheets that assign cost to the orders using:

a. Owner's costing method (Refer to Table 2)

b. Traditional costing method (Refer to and complete Table 3)

c. ABC costing method (Complete Tables 4 \& 5) (Hint: First, create a spreadsheet that costs each of the activities for each order)

2. Evaluate the differences in outcomes, if any. (Produce a table that shows the methods side-by-side)

3. Would you advise one of the costing methods more than the others? Defend your recommendation.

\section{AUTHORS INFORMATION}

Steven P. Landry, Ph.D., CPA (Colorado), CMA, CFM, CGMA, CFP ${ }^{\circledR}$, Senior Lecturer of Accounting, Graduate School of Business \& Public Policy, The Naval Postgraduate School, Ingersoll Building, Room 215A, 555 Dyer Road, Monterey, CA 93943 USA. E-mail: splandry@nps.edu. (Corresponding author)

Canri Chan, Ph.D., CPA (Colorado), Professor of Accounting, Graduate School of International Policy and Management, Monterey Institute of International Studies, A Graduate School of Middlebury College, 460 Pierce Street, Monterey, CA 93940 USA. E-mail: canri.chan@miis.edu

\section{REFERENCES}

1. Ainsworth, P. (1994) When activity-based costing works. The Practical Accountant (July): 28-36.

2. Cooper, R., and R.S Kaplan. (1988) Measure costs right: make the right decisions. Harvard Business Review (September-October): 96-103.

3. Cooper, R., and P.B. Turney. (1989) Hewlett-Packard: The Roseville Network Division. Boston, MA: Harvard Business Press: 188-117.

4. Cooper, R. (1990) Cost classification in unit-based and activity-based manufacturing cost system. Journal of Cost Management (Fall): 4-14.

5. Horngren, C, S. Datar, G. Foster, M. Rajan and C. Ittner. (2009) Cost Accounting: A Managerial Emphasis. $13^{\text {th }}$ ed. Pearson/Prentice-Hall: Upper Saddle River, NJ.

6. Garrison, R., E. Noreen and P. Brewer. (2012) Managerial Accounting. 14 ${ }^{\text {th }}$ ed. McGraw-Hill/Irwin: New York, NY.

7. Jones, L. F. (1991) Product costing at Caterpillar. Management Accounting (February): 34-42.

8. Megginson, L. C., C. R. Scott Jr., L. R. Trueblood, and W. L Megginson, eds. (1988) Successful Small Business Management. $5^{\text {th }}$ edition. US: Business Publications Inc.: 9.

9. Roberts, M. W., and K. J. Silvester. (1996) Why ABC failed and how it may yet succeed. Cost Management (Winter): 23-35.

10. Srinidhi, B. (1992) The hidden cost of specialty products. Journal of Management Accounting Research (Fall) 198- 208.

11. Steinhoff, D., and J. F. Burgess, eds. (1993) Small Business Management Fundamentals. $6^{\text {th }}$ edition. McGraw-Hill International: 14.

12. Turney, P. B. (1991) How activity-based costing helps reduce costs. Journal of Cost Management (Winter): 29- 35. 


\section{APPENDIX I: TRADITIONAL CLASSIFICATION OF MANUFACTURING OVERHEAD}

\begin{tabular}{|c|c|}
\hline Indirect Labor: & $\begin{array}{l}\text { Frame QC (12) } \\
\text { Sewing QC (13) } \\
\text { Assembly QC (2) } \\
\text { Overall QC (1) }\end{array}$ \\
\hline Depreciation: & $\begin{array}{l}\text { Sewer } \\
\text { Cutting Machine } \\
\text { Assembly Machine } \\
\text { Other }\end{array}$ \\
\hline Rent: & $\begin{array}{l}\text { Factory } \\
\text { Warehouse }\end{array}$ \\
\hline Salaries: & $\begin{array}{l}\text { Procurement Clerk } \\
\text { Engineers } \\
\text { Warehouse Workers } \\
\text { Factory Manager \& Account Clerk } \\
\text { Shipping Clerk }\end{array}$ \\
\hline Cleaning: & $\begin{array}{l}\text { Factory } \\
\text { Warehouse } \\
\text { Transportation }\end{array}$ \\
\hline Maintenance: & $\begin{array}{l}\text { Warehouse } \\
\text { Transportation } \\
\text { Cutting Machine } \\
\text { Factory } \\
\text { Sewer }\end{array}$ \\
\hline Transportation: & $\begin{array}{l}\text { Materials } \\
\text { Finished Products }\end{array}$ \\
\hline Indirect Materials: & $\begin{array}{l}\text { Packaging Materials } \\
\text { Sewing Materials } \\
\text { Assembly Materials }\end{array}$ \\
\hline
\end{tabular}

$\begin{array}{r}\$ 3,000.00 \\ 4,500.00 \\ 500.00 \\ 250.00 \\ \hline 6,500.00 \\ 7,500.00 \\ 4,500.00 \\ 1,500.00 \\ \hline 20,000.00 \\ 10,000.00 \\ \hline 8,500.00 \\ 11,200.00 \\ 1,000.00 \\ 16,500.00 \\ 11,500.00 \\ 876.64 \\ 763.20 \\ 375.50 \\ \hline 178.00 \\ 2,811.74 \\ 1,865.00 \\ 889.00 \\ 2,032.20 \\ \hline 13,489.50 \\ 37,427.50 \\ \hline 57,562.08 \\ 5,974.16 \\ 9,388.28 \\ \hline\end{array}$


APPENDIX II: CALCULATIONS OF EQUIVALENT UNITS FOR UNFINISHED ORDERS

\begin{tabular}{|c|c|r|r|r|r|r|r|r|}
\hline Order \# & Delivered & Order Unit & $\begin{array}{c}\text { Frame } \\
\text { Assembly }\end{array}$ & $\begin{array}{c}\text { Cloth } \\
\text { Cutting }\end{array}$ & \multicolumn{1}{c|}{ Sewing } & Packing & $\begin{array}{c}\text { Equivalent } \\
\text { Units }\end{array}$ & N \\
\hline 15 & NO & $1,155.00$ & $1,039.00$ & $1,010.00$ & $1,006.00$ & 996.00 & $1,018.33$ & 1 \\
\hline 16 & NO & $2,457.00$ & $2,591.00$ & $1,760.00$ & $1,768.00$ & $1,728.00$ & $2,039.67$ & 2 \\
\hline 17 & NO & $1,000.00$ & $1,000.00$ & & & & 333.33 & 3 \\
\hline 18 & NO & $1,000.00$ & 994.00 & 640.00 & & & 544.67 & 4 \\
\hline 19 & NO & $3,000.00$ & $2,889.00$ & 600.00 & 575.00 & & $1,354.67$ & 5 \\
\hline 20 & NO & 750.00 & 650.00 & 673.00 & 580.00 & 579.00 & 634.33 & 6 \\
\hline 21 & NO & $1,000.00$ & $1,090.00$ & $1,008.00$ & 650.00 & 600.00 & 916.00 & 7 \\
\hline
\end{tabular}

Note: Completed units would be $100 \%$ complete for equivalent unit purposes. Finished orders plus partially complete orders \#15-21 equaled 17,591 total equivalent units. The work processes of frame assembly, cuttings and sewing are assumed to be $1 / 3$ completed each

Order\#15:1018.33 $=[(1039+1010+1006)-996 \times 3] / 3+996 ;$ Order\#16:2039.67 $=[(2591+1760+1768)-1728 \times 3] / 3+1728 ;$

Order\#17: $333.33=1000 / 3$; Order\#18: 544.67+(994 +640)/3; Order\#19:1354.67 $=(2889+600+575) / 3$;

Order\#20: $634.33=[(650+673+580)-579 \times 3] / 3+579 ;$ Order\#21: $916=[(1090+1008+650)-600 \times 3]+600$ 
APPENDIX III: BREAKDOWN OF ACTIVITIES

\begin{tabular}{|c|c|c|c|c|c|c|c|c|}
\hline \multicolumn{5}{|c|}{ Unit Level Activities } & \multicolumn{4}{|c|}{ Batch Level Activities } \\
\hline Order \# & $\begin{array}{c}\text { Assembly } \\
\text { Activity }\end{array}$ & $\begin{array}{l}\text { Cuttings } \\
\text { Activity }\end{array}$ & $\begin{array}{c}\text { Sewing } \\
\text { Activity }\end{array}$ & $\begin{array}{c}\text { Packaging } \\
\text { Activity }\end{array}$ & $\begin{array}{l}\text { Procure- } \\
\text { ment } \\
\text { Activity }\end{array}$ & $\begin{array}{c}\text { Materials } \\
\text { Handling } \\
\text { Activity }\end{array}$ & $\begin{array}{l}\text { Delivery } \\
\text { Activity }\end{array}$ & $\begin{array}{l}\text { Inspect- } \\
\text { ion } \\
\text { Activity }\end{array}$ \\
\hline 1 & 4,364 & 1,025 & 5,215 & 5,200 & 3 & 15 & 1 & 4 \\
\hline 2 & 5,724 & 519 & 2,720 & 1,500 & 3 & 9 & 1 & 2 \\
\hline 3 & 1,263 & 1,684 & 2,105 & 1,260 & 3 & 4 & 1 & 2 \\
\hline 4 & 4,872 & 2,404 & 2,408 & 3,000 & 3 & 9 & 1 & 2 \\
\hline 5 & 1,050 & 350 & 1,710 & 1,026 & 3 & 4 & 1 & 1 \\
\hline 6 & 400 & 50 & 200 & 150 & 3 & 1 & & 1 \\
\hline 7 & 400 & 100 & 250 & 150 & 3 & 1 & & 1 \\
\hline 8 & 8,505 & 11,600 & 14,025 & 8,400 & 3 & 28 & 2 & 4 \\
\hline 9 & 7,728 & 4,312 & 5,435 & 4,000 & 3 & 15 & 1 & 4 \\
\hline 10 & 4,755 & 1,520 & 7,725 & 4,506 & 3 & 14 & 1 & 4 \\
\hline 11 & 18,720 & 8,020 & 10,500 & 10,010 & 3 & 30 & 1 & 4 \\
\hline 12 & 1,400 & 251 & 1,000 & 800 & 3 & 3 & 1 & 1 \\
\hline 13 & 980 & 560 & 700 & 552 & 3 & 3 & 0.5 & 1 \\
\hline 14 & 1,050 & 600 & 750 & 600 & 3 & 3 & 0.5 & 1 \\
\hline 15 & 7,273 & 4,040 & 4,080 & 3,984 & 3 & 15 & & 4 \\
\hline 16 & 13,137 & 6,840 & 6,840 & 6,912 & 3 & 21 & & 6 \\
\hline 17 & 7,000 & & & & 3 & 5 & & \\
\hline 18 & 6,958 & 2,560 & & & 3 & 7 & & \\
\hline 19 & 8,667 & 600 & 2,875 & & 3 & 18 & & \\
\hline 20 & 5,200 & 2,692 & 2,900 & 2,895 & 3 & 9 & & 2 \\
\hline 21 & 3,270 & 4,032 & 3,250 & 1,800 & 3 & 13 & & 2 \\
\hline No.Activities & 112,716 & 53,759 & 74,688 & 56,745 & 63 & 227 & 12 & 46 \\
\hline Costs & $17,388.28$ & $12,051.23$ & $21,933.42$ & $57,562.08$ & $8,500.00$ & $16,406.83$ & $54,247.27$ & 250.00 \\
\hline Rate & & & & & & & & \\
\hline
\end{tabular}




\section{APPENDIX IV: ACTIVITY- BASED COSTING CLASSIFICATION OF MANUFACTURING OVERHEAD}

Unit-Level Activities:

Assembly:

Cuttings:

Sewing:

Packaging:

Total Unit Level Activity Cost

Batch- Level Activities:

Procurement:

Materials Handling:

Delivery:

Inspection:

Total Batch Level Activity Cost

Frame QC (12)

Assembly QC (2)

Depreciation Assembly Machine

Indirect Assembly Materials

Depreciation Cutting Machine

Other Cutting Activities ${ }^{1}$

Sewing QC (18)

Depreciation Sewer

Other Sewing Activities ${ }^{1}$

Indirect Sewing Materials

Indirect Packaging Materials

Total Unit and Batch Level Activity Costs

Facility-Level Activities:

General Admin.:

Total Activities

Shipping Clerk

Overall QC (1)

Factory Rent and Other Related

Warehouse and Other Related ${ }^{2}$

Factory Manager\&Account Clerk

Employee Benefits

Entertainment \& Other

\section{$\$$}

$3,000.00$

500.00

$4,500.00$

$9,388.28$

$7,500.00$

$4,551.23$

$4,500.00$

$6,500.00$

$4,959.26$

$5,974.16 \quad 21,933.42$

$57,562.08 \quad 57,562.08$

$12,051.23$

$57,562.08$

$108,935.01$

$8,500.00$

$1,000.00$

$15,406.83$

$42,747.29$

$11,500.00$

250.00

$8,500.00$

$16,406.83$

$54,247.29$

250.00

$79,404.12$

$188,339.13$

$24,802.47$

$10,941.20$

$16,500.00$

$8,105.80$

$6,781.90$

$\$$
$79,404.12$

$67,131.37$

$255,470.50$

1. Each noted item was calculated as follows: Total costs - listed items; e.g. other cutting items $=\$ 12,051.23-$ $\$ 7,500=\$ 4,551,23$. Instructor Notes detailing calculations of Total costs available upon request.

2. Warehouse and other related activities $=$ rent + cleaning + maintenance (all from Appendix $I=$ $\$ 10,000+\$ 763.30+\$ 178=\$ 10,941.20$.) 